\title{
Evaluation of leguminous species as cover crops associated with sacha inchi ${ }^{1}$
}

\author{
Reynaldo Solis ${ }^{2}$, Marlon $\mathrm{Pezo}^{2}$, Luis Arévalo², Ceila Lao ${ }^{3}$, Julio Alegre ${ }^{4}, \mathrm{Kevin} \mathrm{Pérez}^{4}$
}

\section{ABSTRACT}

Sacha inchi (Plukenetia volubilis) is an oilseed crop that has gained importance due to the high contents of proteins and unsaturated fatty acids in its seeds. This study aimed at evaluating the growth characteristics of five leguminous species (Crotalaria juncea, Centrosema macrocarpum, Arachis pintoi, Cannavalia ensiformis and Phaseolus vulgaris) used as cover crops, as well as determining their influence on the sacha inchi yield. A complete randomized block design, with three blocks, was used. C. macrocarpum and C. ensiformis were the most appropriate cover crop species for the local edaphoclimatic conditions because they reached $100 \%$ of soil coverage at six months, in addition to controlling the weeds growth and protecting the soil from erosion. Furthermore, the total leaf biomass at six months was significantly higher in C. macrocarpum, what allowed improving the soil fertility through nitrogen cycling. The use of leguminous cover crops, mainly C. macrocarpum, positively influenced the sacha inchi yield.

KEYWORDS: Plukenetia volubilis, foliar biomass, nitrogen cycling.

\section{INTRODUCTION}

Sacha inchi (Plukenetia volubilis) is a new oilseed crop incorporated into the agricultural activity of the Peruvian Amazon (Cachique et al. 2011). It adapts to different types of soils and grows in acid soils with a high aluminum concentration (Céspedes 2006), thus being suitable for use in soil restoration programs and generating positive environmental impacts (Solis et al. 2018).

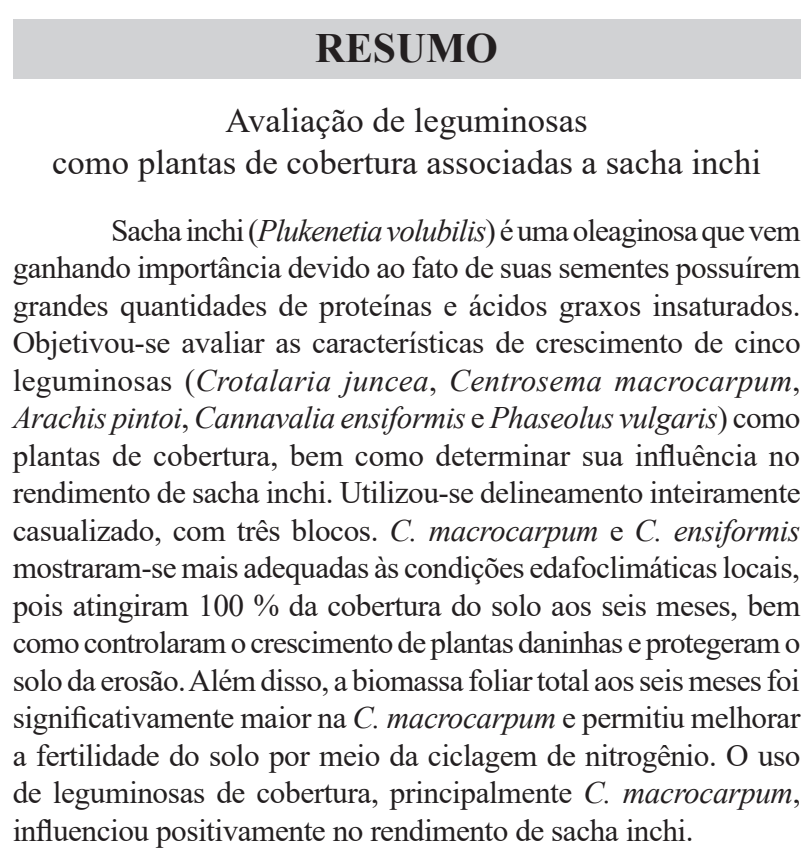

PALAVRAS-CHAVE: Plukenetia volubilis, biomassa foliar, ciclagem de nitrogênio.

Sacha inchi has a high yield potential and has gained importance in the national and international market (Cachique et al. 2011, Valente et al. 2017) due to the high contents of proteins and unsaturated fatty acids in its seeds, mainly omega 3, 6 and 9 (Guillén et al. 2003, Gutiérrez et al. 2011). Besides, the extract of its leaves has antioxidant and antiproliferative activity (Nascimento et al. 2013). Despite such properties, it is underutilized by the pharmaceutical and food industries.

1. Received: Apr. 05, 2019. Accepted: July 16, 2019. Published: Sep. 02, 2019. DOI: 10.1590/1983-40632019v4958011.

2. Instituto de Investigaciones de la Amazonía Peruana, San Martín, Perú.

Email/ORCID: reynaldosolisleyva@gmail.com/0000-0002-5905-4922, jeans.agrof@gmail.com/0000-0001-5769-6350, larevalol@iiap.gob.pe/0000-0002-6417-8161.

3. Universidad Nacional Agraria de la Selva, Facultad de Agronomía, Tingo María, Huánuco, Perú. Email/ORCID: ceipaqui@gmail.com/0000-0002-0125-2133.

4. Universidad Nacional Agraria La Molina, Facultad de Agronomía, Lima, Perú.

Email/ORCID: jalegre@lamolina.edu.pe/0000-0002-7282-045X, kevinperezsald@gmail.com/0000-0002-9874-9663. 
The inadequate management without conservation practices is causing tropical soils to degrade and, consequently, lose their physical, chemical and biological properties (Puertas et al. 2008), also causing a decreased crop yield and poor quality products (Barrios-Maestre et al. 2011), thus calling for alternatives that minimize such risks and allow recovering the soil fertility (SerranoAltamirano \& Cano-García 2007, Alegre et al. 2017).

The use of cover crops, in rotation or associated with crops of economic interest, is an important strategy to improve the soil and environment quality, soil fertility, organic matter accumulation, nitrates leaching mitigation, soil erosion processes reduction and weeds control, as well as the soil biological and physicochemical properties (Arévalo et al. 1998, Bayer et al. 2003, Castillo-Caamal et al. 2010). These benefits will only be efficiently achieved if the selected cover crop species are adapted to the local environmental conditions and are appropriate for the defined agro-ecological target (Bodner et al. 2010).

Cover crop residues in the soil are mainly decomposed by heterotrophic microorganisms that feed on micro and macro elements and use carbon to produce energy and form microbial tissues (Aita et al. 2001). The relevant factors that interfere with the microbial activity are decomposition rate, water regime, availability of inorganic $\mathrm{N}$ in the soil, temperature, $\mathrm{C}: \mathrm{N}$ and lignin: $\mathrm{N}$ ratios, concentrations of lignin and polyphenols, and concentration of $\mathrm{N}$ in plant tissues (Pereira et al. 2017).

The use of leguminous plants as cover crops in production systems allows for the accumulation of organic matter and fixation of atmospheric $\mathrm{N}$ through the symbiotic association with bacteria of the Rhizobium genus (Bayer et al. 2003, Olivera et al. 2005), thus reducing or even eliminating, in some cases, the need to use $\mathrm{N}$ fertilizers (Marinho et al. 2007). Likewise, they have a rapid vegetative development, improve the aggregate stability, increase the carbon content in the soil and contain a greater amount of nutrients, in comparison with other species (Puertas et al. 2008, Rosolem et al. 2016). However, the selection of species as cover crops depends on their adaptability and effects on the main crop (Barrios-Maestre et al. 2011).

There are several studies on the Peruvian Amazon that report the benefits of cover crops associated with various agricultural perennial crops, agroforestry systems and forest plantations, such as Bactris gasipaes, Elaeis guineensis, Inga edulis, Colubrina glandulosa and Guazuma crinita, among others, in addition to benefits in cropping rotation systems with Zea mayz and Vigna unguiculata (Reyes \& Ara 1999, Arévalo et al. 2003, Ara et al. 2004, Puertas et al. 2008, Alegre et al. 2017). Sacha inchi is a climbing and heliophyte crop whose use is difficult in agroforestry systems. Therefore, it is necessary to identify cover crops that can be associated with this species for its sustainable management. In view of that, the present study aimed at evaluating the growth characteristics of leguminous species for use as cover crops, as well as determining their influence on the sacha inchi yield.

\section{MATERIAL AND METHODS}

The study was carried out in the Aguas de Oro village, located in the district of Pinto Recodo, province of Lamas, and in the region of San Martín, in the Peruvian Amazon, in 2016 and 2017. The average annual rainfall and temperature in the study area were $1,800 \mathrm{~mm}$ and $25^{\circ} \mathrm{C}$, respectively. Usually, the rainy season starts approximately in November and ends in May, and there is also a very marked dry period of three months (July, August and September).

Sacha inchi is a climbing species, so it requires a staking system, in order to induce a semi-shrubby behavior and facilitate the harvest. For this reason, a trellis staking system was used in the experiment, so that the plants could develop vertically and bear more fruits. The trellises were installed at a spacing of $3 \mathrm{~m}$ between rows and $6 \mathrm{~m}$ between columns, and the spacing between the plants was $3 \mathrm{~m} \mathrm{x} 3 \mathrm{~m}$.

The weeds were eliminated with a mower before the cover crops were sown, and a wick thread was used as a guiding line for the plants in the trellis systems. Then, the sacha inchi plants were pruned at two months after sowing, with the purpose of obtaining a "Y" forked shape and giving the plant a semi-shrubby behavior, thus facilitating their agronomic management and harvest.

The cover crops were sown in a randomized complete block design, with three blocks. For the study, the main crop consisted of the Mishquiyacu accession of sacha inchi, and the leguminous cover crops planted between the rows of sacha inchi were: crotalaria (Crotalaria juncea), centrosema (Centrosema macrocarpum), forage peanut (Arachis 
pintoi), canavalia (Cannavalia ensiformis) and bean (Phaseolus vulgaris), in addition to a control treatment without cover crop, thus totaling six treatments. The cover crops were sown at a distance of $0.5 \mathrm{~m} \times 0.5 \mathrm{~m}$. For each experimental unit, 20 sacha inchi plants were used, with 120 plants established in each block, and finally 360 sacha inchi plants established throughout the experimental plot, within an area of $3,400 \mathrm{~m}^{2}$.

To control any possible influence of fertilization on the variables under study, the same fertilizer dosage was used throughout the experimental plot, thus isolating this factor during the establishment of the blocks. For soil recovery, $40 \mathrm{~kg}$ of $\mathrm{P} \mathrm{ha}^{-1}$ were applied before the cover crops were sown (Alegre et al. 2017). In addition, $1.5 \mathrm{~kg}$ of earthworm humus were applied per plant of sacha inchi during sowing, by making a half-moon shaped hole $30 \mathrm{~cm}$ away from the base of the plant. Six months later, the same dosage of earthworm humus was applied again to each sacha inchi plant.

The variables evaluated in the experimental plot were: coverage percentage, leaf biomass, root biomass, root depth, $\mathrm{N}$ content in the soil and sacha inchi yield. The evaluation of the variables, except for the sacha inchi yield, was carried out according to Puertas et al. (2008). The coverage percentage was evaluated by using photographic images (four for each plot) for six months, with a monthly frequency, and then processed by the Asses software. For the evaluation of the leaf biomass, a wooden quadrant of $1 \mathrm{~m}^{2}$ was placed on the cover crop and all plant material thereof was collected to determine the fresh weight. Subsequently, two sub-samples were separated and dried at $72{ }^{\circ} \mathrm{C}$, for $72 \mathrm{~h}$, to determine the dry weight. To determine the root biomass, two wooden quadrants of $0.25 \mathrm{~m} \times 0.25 \mathrm{~m}$ were used, in addition to two points located within the quadrant, used for the leaf biomass evaluation. For this, roots of each cover crop were collected at a depth of $50 \mathrm{~cm}$, then washed and dried at room temperature, and subsequently the same procedure described for leaf biomass was applied. To evaluate the root depth, three soil pits of $0.5 \mathrm{~m} \times 0.5 \mathrm{~m} \times 0.5 \mathrm{~m}$ were made in each experimental unit. The evaluation of leaf biomass, root biomass and root depth were performed at six months after the cover crops were sown. The $\mathrm{N}$ content in the soil was estimated indirectly and corresponded to $4.5 \%$ of the organic matter content, which was determined using the method by Walkley \& Black (1934). The N content in the soil was evaluated one year after sowing the cover crops. The sacha inchi yield was determined by individually evaluating all plants during one year of harvest.

All data were registered in an Excel database and then, using the statistical software R 3.5.1. and the package "agricolae", they were subjected to analysis of variance, and means were compared by the the Tukey test at a $5 \%$ significance level.

\section{RESULTS AND DISCUSSION}

The initial characteristics of the soil in the experimental plot before the establishment of the sacha inchi plants were as it follows: $\mathrm{pH}=3.88$; electrical conductivity $=0.26 \mathrm{dS} \mathrm{m}^{-1} ; \mathrm{CaCO}_{3}<0.3 \%$; organic matter $=3.13 \% ; \mathrm{N}=0.14 \% ; \mathrm{P}=12.21 \mathrm{ppm}$; and $\mathrm{K}=70 \mathrm{ppm}$. The soil physicochemical analysis was carried out one year after the cover crops were sown and no significant changes were observed, except for the organic matter and $\mathrm{N}$ content in the soil.

The first evaluation was performed one month after sowing and the coverage percentage was statistically higher in canavalia (38.8\%), if compared to that in the other species (between $4.7 \%$ and $17.9 \%$ ) (Table 1). Over the time, there was an increase in the coverage percentage of the different leguminous species, with statistical differences

Table 1. Coverage percentage of the leguminous cover crops.

\begin{tabular}{lcccccc}
\hline \multicolumn{1}{c}{ Species } & \multicolumn{5}{c}{ Coverage percentage (days after sowing) } \\
\cline { 2 - 6 } & 30 & 60 & 90 & 120 & 150 & 180 \\
\hline Crotalaria juncea & $7.5 \mathrm{c} *$ & $13.1 \mathrm{~cd}$ & $54.3 \mathrm{~b}$ & $65.9 \mathrm{~b}$ & $86.6 \mathrm{~b}$ & $96.3 \mathrm{a}$ \\
Centrosema macrocarpum & $7.8 \mathrm{c}$ & $16.7 \mathrm{c}$ & $51.5 \mathrm{~b}$ & $73.9 \mathrm{~b}$ & $95.2 \mathrm{ab}$ & $100.0 \mathrm{a}$ \\
Arachis pintoi & $4.7 \mathrm{c}$ & $11.0 \mathrm{~d}$ & $16.3 \mathrm{c}$ & $21.9 \mathrm{c}$ & $41.6 \mathrm{c}$ & $60.9 \mathrm{~b}$ \\
Cannavalia ensiformis & $38.8 \mathrm{a}$ & $79.5 \mathrm{a}$ & $90.6 \mathrm{a}$ & $95.8 \mathrm{a}$ & $100.0 \mathrm{a}$ & $100.0 \mathrm{a}$ \\
Phaseolus vulgaris & $17.9 \mathrm{~b}$ & $53.5 \mathrm{~b}$ & $53.7 \mathrm{~b}$ & - & - & - \\
\hline
\end{tabular}

* Averages in the same column followed by different letters indicate significant differences $(\mathrm{p}<0.05)$ among the treatments. 
between them, being canavalia the species that was statistically superior in all evaluations. At five months after sowing, it was observed that canavalia reached $100 \%$ of coverage, while forage peanut reached only $41.6 \%$, being statistically lower than the rest of the treatments. At six months after sowing, both canavalia and centrosema presented $100 \%$ of coverage, whereas crotalaria and forage peanut reached $96.3 \%$ and $60.9 \%$, respectively (Table 1 ), what led to the development of weeds. Puertas et al. (2008) also reported that canavalia and centrosema reached $100 \%$ of coverage, when compared to other species at three and five months after sowing, respectively, while Arévalo et al. (2003) reported that centrosema reached $100 \%$ of coverage at four months after sowing. The differences in terms of the time that canavalia and centrosema took to reach $100 \%$ of coverage in those studies would relate mainly to the variations in the edaphoclimatic conditions of the studied areas, but in all cases the two species had the best vegetative development.

On the other hand, bean reached $53.7 \%$ of coverage at three months, and then, at four months, the bean plants began to die, because they completed their phenological cycle. The advantage of this species is that its seeds are edible and can provide additional incomes to farmers, but the disadvantage is that plants complete their vegetative cycle in approximately four months, so they need to be replanted.

One important point to consider when choosing a cover crop is the time in which it covers and protects the soil surface (Puertas et al. 2008). According to the results of the present study, canavalia and centrosema can be established in sacha inchi crops because they covered the soil in less time and controlled the weed growth from the third month after their establishment. Besides, they protected the soil from erosion and sacha inchi plants from water stress. These advantages are also mentioned by Sancho \& Cervantes (1997), who reported that cover crops should not represent a competition for the main crop, but, in turn, should prevent the soil erosion and weed growth.

Cover crops can produce high volumes of leaf biomass, thus improving the surface cover and providing high amounts of different types of organic matter to the soil (Pereira et al. 2017). In the present study, the leaf biomass (stems and leaves) was determined at six months after the experiment started, except for beans, whose leaf biomass was determined at four months, due to its short vegetative cycle.

The biomass produced by all the evaluated leguminous species was greater than $2 \mathrm{t} \mathrm{ha}^{-1}$, being sufficient to fulfill the function of a cover crop by providing organic material to the soil (CastilloCaamal et al. 2010). The leaf biomass produced by centrosema in sacha inchi crops was statistically higher $\left(8.6 \mathrm{t} \mathrm{ha}^{-1}\right)$, if compared to the other treatments; however, bean produced the lowest leaf biomass (3.1 $\mathrm{t} \mathrm{ha}^{-1}$ ) (Table 2). Alegre et al. (2017) reported that centrosema produced an amount of leaf biomass ranging between $7.20 \mathrm{tha}^{-1}$ and $9.77 \mathrm{tha}^{-1}$ in different agroforestry systems. Puertas et al. (2008) also found that this species had the highest leaf biomass in the assessment of cover crops in the Peruvian Amazon. These results support the statement that the higher biomass production and higher nutrient concentration in cover crops, as seen in centrosema, facilitate the soil fertility recovery in various agricultural systems (Arévalo et al. 2003, Ara et al. 2004, Alegre et al. 2017). Pereira et al. (2017) reported that the factors associated with the increase of leaf biomass in cover crops are the species used, planting density and the average annual rainfall.

Roots absorb water and nutrients from the soil, so longer roots facilitate this process. Besides, after approximately one year, decomposed roots increase

Table 2. Leaf and root development characteristics of the leguminous cover crops and the $\mathrm{N}$ content in the soil.

\begin{tabular}{lcccc}
\hline \multicolumn{1}{c}{ Species } & Leaf biomass $\left(\mathrm{t} \mathrm{ha}^{-1}\right)$ & Root biomass $\left(\mathrm{t} \mathrm{ha}^{-1}\right)$ & Root depth $(\mathrm{cm})$ & N content in the soil $(\%)$ \\
\hline Control & - & - & - & $0.14 \mathrm{~d}$ \\
Crotalaria juncea & $4.7 \mathrm{~b}^{*}$ & $2.2 \mathrm{~b}$ & $18.2 \mathrm{bc}$ & $0.15 \mathrm{c}$ \\
Centrosema macrocarpum & $8.6 \mathrm{a}$ & $2.4 \mathrm{~b}$ & $20.6 \mathrm{~b}$ & $0.20 \mathrm{a}$ \\
Arachis pintoi & $4.8 \mathrm{~b}$ & $3.0 \mathrm{a}$ & $28.7 \mathrm{a}$ & $0.13 \mathrm{e}$ \\
Cannavalia ensiformis & $4.4 \mathrm{~b}$ & $1.5 \mathrm{c}$ & $11.9 \mathrm{~cd}$ & $0.17 \mathrm{~b}$ \\
Phaseolus vulgaris & $3.1 \mathrm{c}$ & $1.5 \mathrm{c}$ & $8.8 \mathrm{~d}$ & $0.15 \mathrm{c}$ \\
\hline
\end{tabular}

* Averages in the same column followed by different letters indicate significant differences $(p<0.05)$ among the treatments. 
the content of organic matter and nutrients in the soil, because they leave ducts through the different soil layers, thus facilitating the aeration and water penetration (Navarro-Garza et al. 2007). In addition to environmental benefits, such as the increase of soil organic matter, the practice of cover crops has positive effects on the cation exchange capacity (Bayer et al. 2003).

The results of root biomass for the different cover crops showed significant differences among them, being forage peanut the species that presented the largest amount of root biomass $\left(3\right.$ tha $\left.^{-1}\right)$ (Table 2$)$. On the other hand, centrosema and canavalia, with $2.4 \mathrm{tha}^{-1}$ and $1.5 \mathrm{tha}^{-1}$, respectively, presented lower values in comparison to forage peanut, but similar to the results obtained by Puertas et al. (2008), who reported $2.76 \mathrm{t} \mathrm{ha}^{-1}$ and $1.78 \mathrm{t} \mathrm{ha}^{-1}$ for centrosema and canavalia, respectively. Likewise, according to Guerra et al. (2005), differences in climate and soil physicochemical characteristics may explain the variability in the production of fine and coarse roots in different study sites. However, in the present study, the different cover crops were evaluated under similar edaphoclimatic conditions, hence the differences found were due to the plant species used.

Root depth plays an important role in anchoring, soil aeration, soil organic carbon content and water and nutrient absorption (Canadell et al. 1996, Oderiz et al. 2017). In the present study, forage peanut showed the greatest root depth $(28.7 \mathrm{~cm})$ and was significantly different, if compared with the depths reached by the other species. This result is related with the high value of root biomass obtained; however, this species showed the lowest leaf biomass production and the lowest coverage percentage, in comparison with the other cover crops. On the other hand, centrosema was the second species that presented the highest value for root depth $(20.6 \mathrm{~cm})$, in addition to obtaining the highest leaf biomass content and reaching $100 \%$ of coverage at 180 days after sowing (Table 2).

Although Canadell et al. (1996) argued that the use of leguminous plants as cover crops increases the organic matter and improves the structure and retentive capacity of soils due to the production of deeper roots and greater amounts of root biomass, the functional significance of root depth and its contribution to all ecosystem processes are still not well understood (Puertas et al. 2008). The root decomposition rate varies according to the depth in the soil (Gill \& Burke 2002). Therefore, the study of root depth and distribution would contribute to a better understanding of the nutrient cycling process (Jobbágy \& Jackson 2001, Oderiz et al. 2017), pointing to the need of further studies analyzing the contribution of roots to the dynamics of nutrients in the productive systems of tropical regions.

It is worth mentioning that one year after the cover crops were sown, a soil physicochemical analysis was carried out and, in that short time, the cover crops did not influence the soil physicochemical properties, except for the organic matter and $\mathrm{N}$ content.

Leguminous species have the ability to fix atmospheric $\mathrm{N}$ by symbiotic fixation through bacteria of the Rhizobium genus (Olivera et al. 2005). Due to the fact that the study was conducted on soils with similar physicochemical characteristics in all cover crops, the $\mathrm{N}$ content is an indicator of the amount of $\mathrm{N}$ supplied by the cover crop. In this regard, centrosema had a statistically higher value $(0.20 \%)$, when compared to the rest of the cover crops, while the control treatment $(0.14 \%)$ and forage peanut $(0.13 \%)$ showed the lowest $\mathrm{N}$ content (Table 2). The high amount of $\mathrm{N}$ supplied by centrosema is due to the symbiotic fixation of $\mathrm{N}_{2}$ and the amount of biomass produced, as reported by Pereira et al. (2017) for Vicia sativa.

The study conducted by Puertas et al. (2008) in the Peruvian Amazon determined that the amount of N (311 kg ha $\left.{ }^{-1}\right), P\left(24.97 \mathrm{~kg} \mathrm{ha}^{-1}\right)$ and $\mathrm{K}\left(155.61 \mathrm{~kg} \mathrm{ha}^{-1}\right)$ extracted for centrosema was significantly higher than those extracted for other cover crops. Therefore, this species develops a $\mathrm{N}_{2}$-fixing capacity with greater efficiency, represents an extra supply of $\mathrm{N}$ and contributes to the $\mathrm{N}$ cycle. Moreover, this cover crop is better adapted to the tropical region and has a greater specificity with bacteria of the Rhizobium genus (Arévalo et al. 2003, Puertas et al. 2008). Such characteristics indicate that the association between sacha inchi and centrosema is a promising alternative for systems that need simultaneously the protection of soils against erosive processes and the supply of $\mathrm{N}$ to crops.

The yield per hectare of a crop is influenced by edaphoclimatic, genetic and nutritional factors, and, in this study, all treatments were exposed to the same conditions. Cachique et al. (2008) reported that the yield potential of the Mishquiyacu accession used in this study is $2,025.3 \mathrm{~kg} \mathrm{ha}^{-1}$ year ${ }^{-1}$. Sacha inchi plots 


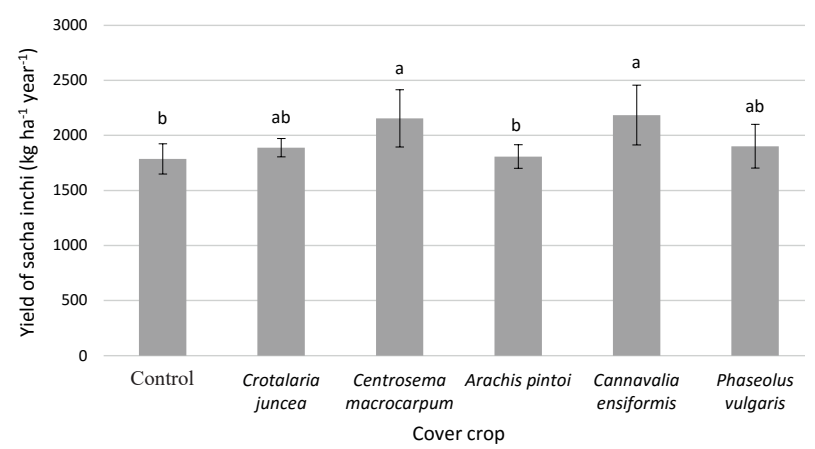

Figure 1. Sacha inchi yield in association with leguminous cover crops. Values in the bars with different letters indicate significant differences $(p<0.05)$ among the treatments.

that had centrosema and canavalia as cover crop presented similar yields $\left(2,154.6 \mathrm{~kg} \mathrm{ha}^{-1}\right.$ year $^{-1}$ and $2,184.3 \mathrm{~kg} \mathrm{ha}^{-1}$ year $^{-1}$, respectively) and were statistically superior to the control treatment $\left(1,787.4 \mathrm{~kg} \mathrm{ha}^{-1}\right.$ year $\left.^{-1}\right)$ (Figure 1). Conversely, Rodrigues et al. (2014) reported a yield of $155.5 \mathrm{~kg} \mathrm{ha}^{-1}$ in sacha inchi plants propagated by seeds at 14 months after sowing, which is approximately six months after the beginning of the harvest season. The yield obtained in their study was lower, if compared to the results obtained in the present study, and may be influenced by genetic and/ or edaphoclimatic factors.

These results indicate that agricultural main crops associated with cover crops are a viable alternative, when compared to monocultures, considering the fact that the sacha inchi yield was increased by $18.2 \%$ when associated with centrosema, in comparison to the control treatment. Similar results were obtained by Pereira et al. (2017), in associations of Avena sativa and Vicia sativa. Furthermore, it is worth noting that local farmers use centrosema as fodder for guinea pigs and livestock, and may also generate extra incomes by selling their seeds.

The obtained results show the importance of continuing these studies for long periods, in order to determine the specific soil coverage for each one of the tropical crops and evaluate the changes in the soil physicochemical properties due to the use of cover crops.

\section{CONCLUSIONS}

Centrosema and canavalia are the most appropriate leguminous cover crops to control the weed growth and protect the soil from erosion.
Between them, centrosema was superior and showed better results in the improvement of soil fertility through nutrient cycling, since it presented a greater leaf biomass and adequate root development. Additionally, the $\mathrm{N}$ content in the soil was higher, thus positively influencing the sacha inchi yield.

\section{ACKNOWLEDGMENTS}

The authors would like to thank Innovate Perú FIDECOM for financially supporting this study.

\section{REFERENCES}

AITA, C.; BASSO, C. J.; CERETTA, C. A.; GONÇALVES, C. C.; DA ROS, C. O. Plantas de cobertura de solo como fonte de nitrogênio ao milho. Revista Brasileira de Ciência do Solo, v. 25, n. 1, p. 157-165, 2001.

ALEGRE, J.; LAO, C.; SILVA, C.; SCHREVENS, E. Recovering degraded lands in the Peruvian Amazon by cover crops and sustainable agroforestry systems. Peruvian Journal of Agronomy, v. 1, n. 1, p. 1-7, 2017.

ARA, M.; REYES, C.; RAMOS, O.; ClAVO, Z. Fertilización con fósforo y control de malezas para el establecimiento de Brachiaria brizantha a escala comercial. Revista de Investigaciones Veterinarias del Perú, v. 15, n. 2, p. 92-99, 2004.

ARÉVALO, L. A.; ALEGRE, J. C.; BANDY, D. E.; SZOTT, L. T. The effect of cattle grazing on soil physical and chemical properties in a silvopastoral system in the Peruvian Amazon. Agroforestry System, v. 40, n. 2, p. 109124, 1998.

ARÉVALO, L. A.; ALEGRE, J. C.; FASABI, R. Efecto del fósforo sobre el establecimiento del Centrosema macrocarpum Benth dentro de una plantación de pijuayo (Bactris gasipaes H.B.K.) en un Ultisol del trópico húmedo. Ecología Aplicada, v. 2, n. 1, p. 93-97, 2003.

BARRIOS-MAESTRE, R.; FARIÑAS, J.; SILVAACUÑA, R.; SANABRIA, D. Comportamiento de cinco especies de leguminosas como cobertura viva en palma aceitera en el estado Monagas, Venezuela. Idesia, v. 29, n. 2, p. 29-37, 2011.

BAYER, C.; SPAGNOLLO, E.; WILDNER, L. P.; ERNANI, P. R.; ALBURQUEQUE, J. A. Incremento de carbono e nitrogênio num Latossolo pelo uso de plantas estivais para cobertura do solo. Ciência Rural, v. 33, n. 3, p. 469-475, 2003.

BODNER, G.; HIMMELBAUER, M.; LOISKANDL, W.; KAUL, H. P. Improved evaluation of cover crop species 
by growth and root factors. Agronomy for Sustainable Development, v. 30, n. 2, p. 455-464, 2010.

CACHIQUE, D.; VASQUEZ, G.; MERINO, C.; SOTERO, $\mathrm{V}$. Avances en identificación de genotipos de sacha inchi (Plukenetia volubilis L.) con características deseables y sobresalientes. San Martín: IIAP, 2008.

CACHIQUE, D.; RODRIGUEZ, A.; RUIZ-SOLSOL, H.; VALLEJOS, G.; SOLIS, R. Propagación vegetativa del sacha inchi (Plukenetia volubilis L.) mediante enraizamiento de estacas juveniles en cámaras de subirrigación en la Amazonía Peruana. Folia Amazónica, v. 20, n. 1-2, p. 95-100, 2011.

CANADELL, J.; JACKSON, R. B.; EHLERINGER, J. B.; MOONEY, H. A.; SALA, O. E.; SCHULZE, E. D. Maximum rooting depth of vegetation types at the global scale. Oecología , v. 108, n. 4, p. 583-595, 1996.

CASTILLO-CAAMAL, J. B.; CAAMAL-MALDONADO, J. A.; JIMENEZ-OSORNIO, J. M.; BAUTISTA-ZUÑIGA, F.; AMAYA-CASTRO, M. J.; RODRIGUEZ-CARRILLO, R. Evaluación de tres leguminosas como coberturas asociadas con maíz en el trópico subhúmedo. Agronomía Mesoamericana, v. 21, n. 1, p. 39-50, 2010.

CÉSPEDES, E. I. M. Cultivo de sacha inchi. San Martín: INIIA, 2006.

GILL, R. A.; BURKE, I. C. Influence of soil depth on the decomposition of Bouteloua gracilis roots in the shortgrass steppe. Plant and Soil, v. 241, n. 2, p. 233-242, 2002.

GUERRA, J.; GAYOSO, J.; SCHLATTER, J.; NESPOLO, R. Análisis de la biomasa de raíces en diferentes tipos de bosques: avances en la evaluación de Pinus radiata en Chile. Bosque, v. 26, n. 1, p. 5-21, 2005.

GUILLÉN, M. D.; RUIZ, A.; CABO, N.; CHIRINOS, R.; PASCUAL, G. Characterization of sacha inchi (Plukenetia volubilis $\mathrm{L}$.) oil by FTIR spectroscopy and H NMR: comparison with linseed oil. Journal of the American Oil Chemists'Society, v. 80, n. 8, p. 755-762, 2003.

GUTIÉRREZ, L. F.; ROSADA, L. M.; JIMENEZ, A. Chemical composition of sacha inchi (Plukenetia volubilis L.) seeds and characteristics of their lipid fraction. Grasas y Aceites, v. 62, n. 1, p. 76-83, 2011.

JOBBÁGY, E. G.; JACKSON, R. B. The distribution of soil nutrients with depth: global patterns and the imprint of plant. Biogeochemistry, v. 53, n. 1, p. 51-77, 2001.

MARINHO, G. J.; NDIAYE, A.; ASSIS, R. L. DE; AZEVEDO, J. E. Cultivos de cobertura como indicadores de procesos ecológicos. Leisa, v. 22, n. 4, p. 20-22, 2007.

NASCIMENTO, A. K. L.; MELO-SILVEIRA, R. F.; DANTAS-SANTOS, N.; FERNANDES, J. M.; ZUCOLOTTO, S. M.; ROCHA, H. A. O.; SCORTECCI,
K. C. Antioxidant and antiproliferative activities of leaf extracts from Plukenetia volubilis Linneo (Euphorbiaceae). Evidence-Based Complementary and Alternative Medicine, 950272, 2013.

NAVARRO-GARZA, H.; PÉREZ-OLVERA, M. A.; CASTILLO-GONZÁLEZ, F. Evaluación de cinco especies vegetales como cultivos de cobertura en valles altos de México. Revista Fitotecnia Mexicana, v. 30, n. 2, p. 151157, 2007.

ODERIZ, J. A.; UHALDEGARAY, M. G.; FRASIER, I.; QUIROGA, A. R.; AMIOTTI, N.; ZALBA, P. Raíces de cultivos de cobertura, cantidad, distribución e influencia sobre el mineral. Ciencia del Suelo, v. 35, n. 2, p. 249258, 2017.

OLIVERA, Y.; MACHADO, R.; RAMIREZ, J.; CEPERO, B. Evaluación de una colección de Centrosema spp. en un suelo ácido. Pastos y Forrajes, v. 28, n. 2, p. 99-106, 2005.

PEREIRA, E.; GALANTINI, J. A.; QUIROGA, A. Calidad de cultivos de cobertura en sistemas de siembra directa del sudoeste bonaerense. Ciencia del Suelo, v. 35, n. 2, p. 337-350, 2017.

PUERTAS, F.; AREVALO, E.; ZUÑIGA, L.; ALEGRE, J.; LOLI, O.; SOPLIN, H.; BALIGAR, V. Establecimiento de cultivos de cobertura y extracción total de nutrientes en un suelo de trópico húmedo en la Amazonía Peruana. Ecología Aplicada, v. 7, n. 1-2, p. 23-28, 2008.

REYES, A.; ARA, M. Tasas de siembra y fertilización con P para el establecimiento de Centrosema macrocarpum en Pucallpa. Revista de Investigaciones Veterinarias del Perú, v. 10, n. 1, p. 54-62, 1999.

RODRIGUES, P. H. V.; BORDIGNON, S. R.; AMBROSANO, G. M. B. Desempenho horticultural de plantas propagadas in vitro de sacha inchi. Ciência Rural, v. 44, n. 6, p. 1050-1053, 2014.

ROSOLEM, C. A.; LI, Y.; GARCIA, R. A. Soil carbon as affected by cover crops under no-till under tropical climate. Soil Use and Management, v. 32, n. 4, p. 495503, 2016.

SANCHO, F.; CERVANTES, C. El uso de plantas de cobertura en sistemas de producción de cultivos perennes y anuales en Costa Rica. Agronomía Costarricense, v. 21, n. 1, p. 111-120, 1997.

SERRANO-ALTAMIRANO, V.; GARCÍA-CANO, M. A. Leguminosas de cobertura para reducir la erosión y mejorar la fertilidad de suelo de ladera. Terra Latinoamericana, v. 25, n. 4 , p. 427-435, 2007.

SOLIS, R.; CACHIQUE, D.; GUERRERO-ABAD, J. C.; RUIZ, M. E.; TAPIA Y FIGUEROA, L. In vitro 
propagation of sacha inchi through organogenesis. inchi progenies. Pesquisa Agropecuária Tropical, v. 47, Pesquisa Agropecuária Brasileira, v. 53, n. 11, p. 1285- n. 4, p. 480-487, 2017.

1288, 2018.

WALKLEY, A.; BLACK, C. A. An examination of the VALENTE, M. S. F.; LOPES, M. T. G. ; CHAVES, F. C. Degtajareff's method for determining soil organic matter M. ; PANTOJA, M. C.; SOUSA, G. M. G.; CHAGAS, E. and a proposed modification of the chromic acid titration A. Molecular genetic diversity and mating system in sacha method. Soil Science, v. 37, n. 1, p. 29-38, 1934. 